\title{
Immunohistochemistry of Heat Shock Protein 70 (Hsp70) on Earthworm (Lumbricus terrestris) in Gold Mining Sites
}

\author{
Setya Widi Ayuning \\ Graduate student, Faculty of Fisheries and Marine Science, University of Brawijaya, \\ Indonesia \\ E-mail: setya_widhi3@yahoo.com \\ Diana Arfiati \\ Aquatic Resources Management Studies (LSIH), Faculty of Fisheries and Marine \\ Science,University of Brawijaya, Indonesia \\ E-mail: d_arfiati@yahoo.com
}

Yenny Risjani

Central Laboratory of Life Biological Sciences, University of Brawijaya, Indonesia E-mail:yenni_risjani@yahoo.com

Received: July 20, 2014 Accepted: August 20, 2014 Published: September 20, 2014

Doi: 10.5296/jab.v2i2.6403 URL: http://dx.doi.org/10.5296/jab.v2i2.6043

\begin{abstract}
The traditional gold mining in Cempaka, Banjarbaru, South Kalimantan, Indonesia used mercury in order to separate the gold with a fine sand and rocks. Mercury can impair the function of the cellular and organism physiology that live in the mining sites. In cellular on earthworm may adapt to help in repairing cell damage with expression of HSP70 proteins. This study was conducted in November 2012 to September 2014. Sampling of soil and earthworms do in Banjarbaru village (control) and in paddy field near gold mining among them Murung village, Pumpung village and Palam village (ex. PT. Galuh Cempaka). Soil quality in the gold mining indicate conditions are still good in term of $\mathrm{C}$-organic, $\mathrm{pH}$ and CEC. The C-organic content of the soil between the $2.08-2.52 \%$; the value of $\mathrm{pH} \mathrm{H}_{2} \mathrm{O}$
\end{abstract}


between 4.90-5.72, CEC between 17.20-18.11. Detection of protein HSP70 on earthworms use the method immunohistochemistry. HSP70 expression was found in the longitudinal muscle layer (LM). The expression of HSP70 most occurred in earthworms that live in the land of the paddy fields ex. PT. Galuh Cempaka.

Keywords: HSP70, Soil quality

\section{Introduction}

Gold mining located in Pumpung village, Murung village and Palam village (ex. PT. Galuh Cempaka), Cempaka District, South Kalimantan are traditional gold mining. To find the gold, miner conducts some phases, for some is washing phase. In this phase, the miner uses mercury powder to separate the gold with a fine sand and rocks. Waste produced from washing phase is directly disposed to bodies of water. For what it is known that the waste produced by this phase contains mercury compound. During rainy season, mercury compound existing in waters will be distributed to surrounding ground level (Bleeker \& Gestel, 2007).

Earthworm in family Lumbricidae lives in $90 \%$ of soil biomass. It plays an important role to keep the soil fertile and it is nutrient recycling. Lumbricus terrestris can be employed as soil pollution bioindicator (Viega \& Hinton, 1999; Zhang et al., 2009; Lee, 1985). Earthworm is tolerant to heavy metal contamination and it has capacity to accumulate heavy metal in the tissue. Thus, presence of Lumbricidae earthworm species becomes environmental protector (Lukkari et al., 2004).

Existence of mercury in soil can affect physiological condition as well cellular homeostasis of soil biota, such as earthworm. In cellular adaptation, earthworm inducts stress proteins called heat shock protein 70 (HSP70). Lumbricus terrestris is so sensitive to existence of chemicals in its habitat (Nadeau et al., 2001; Robert, 2003). It is deemed that HSP70 has an important role in adaptive resistance development to various environmental stress (Krebs \& Bettencourt, 1999; Sorensen et al., 2003). It also counts existence of heavy metal in the soil such as mercury (Kohler et al., 1992). This protein can increase cell survival rate by decreasing damaged and abnormal polypeptide within a cell (Feder \& Hofmann, 1999). Research objectives are to if find out if living Lumbricus terrestris in gold mining sites will express protein HSP70 to face polluted environment from mercury.

\section{Materials and Procedures}

\subsection{Location and Sampling}

Soil area sampling and Lumbricus terrestris sampling are taken in three selected stations based on kinds of surrounding activities which can pollute the environment. The three stations are gold mining sites in Murung village (11450'55,0'E, 3`30'03,3'S), Pumpung village $\left(114^{\circ} 50^{\prime} 30,8^{\prime} \mathrm{E}, 3^{\circ} 30^{\prime} 21,4^{\prime}\right.$ 'S) and Palam village (Ex. PT. Galuh Cempaka) at ordinate of $114^{\circ} 46^{\prime} 31,7^{\prime \prime} \mathrm{E}, 3^{\circ} 30^{\prime} 25,8^{\prime}$ 'S. Uncontaminated soil taken from Banjarbaru village is used as control variable.

Soil sample is taken from a depth of $0-15 \mathrm{~cm}$ at weight of $1 \mathrm{~kg}$ by using PVC pipe. The soil sample, then, is put into plastic pocket, labeled and added by concentrated acid $\mathrm{HNO}_{3}$ and stored in a coolbox with dry ice therein. Soil sample is tested to determine soil physical and 


\section{Macrothink

chemical quality including soil texture, C-organic (Walkley \& Black method), $\mathrm{pH}\left(\mathrm{pH} \mathrm{H}_{2} \mathrm{O}\right.$ and $\mathrm{pH} \mathrm{KCl}$ ) and CEC. Every station takes 15 Lumbricus terrestris at 5-10 cm in length and 0.3-0.4 gram in weight and put them into plastic pocket with uncontaminated soil inside (Homa et al., 2005).

\subsection{Immunohistochemical Analysis Using HSP70}

Preparation of Lumbricus terrestris uses muscular wall of the worm. First, Lumbricus terrestris is washed by distilled water, then it gets fixation by using EDTA solution, dehydration by using graded alcohol, clearing with graded xylol, embedding by using paraffin, and last, it is diagonally sliced 4-7 $\mu \mathrm{m}$ in thickness (Amaral et al., 2006). Staining to preparation uses Dako LSAB+ Kit HSP70 (3A3): sc-32239, sytem-HRP (biotinylated link is an anti-mouse; anti-rabbit; anti-goat immunoglobin, streptavidin-HRP, DAB+substrat buffer, $\mathrm{DAB}+$ cromagen).

\subsection{Total Mercury}

Soil sample and Lumbricus terrestris of $100 \mathrm{mg}$ (gross weight) is added by chemical preservation solution of concentrated acid $\mathrm{HNO}_{3}$ by $1 \mathrm{ml}$ (Pedreros et al., 2011). Mixed sample is dried up to become ashes at temperature of $45-55{ }^{\circ} \mathrm{C}$ by employing Atomic Absorption spectrophotometry (AAS).

\section{Findings}

Traditional gold mining activity conducted by community around Murung village, Pumpung village and Palam village (ex. PT. Galuh Cempaka) affects negatively soil physical and chemical quality, as presented in Table 1.

Table 1. Physical and chemical properties of soil

\begin{tabular}{|c|c|c|c|c|}
\hline \multicolumn{5}{|c|}{ Nature of Physics } \\
\hline No. & Station & Parameter & Value & PPT (1983) \\
\hline \multirow[t]{4}{*}{1.} & Controls & \multirow{4}{*}{$\begin{array}{l}\text { The weight of } \\
\text { Contents } \\
\left(\mathrm{gr} / \mathrm{cm}^{3}\right)\end{array}$} & 0,90 & Texture Clay \\
\hline & 1 & & 1,34 & Texture Clay \\
\hline & 2 & & 1,28 & Texture Clay \\
\hline & 3 & & 1,30 & Texture Clay \\
\hline \multirow[t]{8}{*}{2.} & & Soil texture & & \\
\hline & \multirow[t]{3}{*}{ Controls } & Sand $(\%)$ & 40 & \multirow{3}{*}{$\begin{array}{l}\text { Clayey } \\
\text { (Texture Clay) }\end{array}$} \\
\hline & & Dust (\%) & 17 & \\
\hline & & Clay $(\%)$ & 43 & \\
\hline & \multirow[t]{3}{*}{1} & Sand $(\%)$ & 62 & \multirow{3}{*}{$\begin{array}{l}\text { Sandy Clay Loam } \\
\text { (Texture Clay) }\end{array}$} \\
\hline & & Dust (\%) & 13 & \\
\hline & & Clay(\%) & 25 & \\
\hline & 2 & Sand (\%) & 68 & Sandy Clay Loam \\
\hline
\end{tabular}




\begin{tabular}{|c|c|c|c|c|}
\hline & & Dust (\%) & 10 & (Texture Clay) \\
\hline & & Clay $(\%)$ & 22 & \\
\hline & 3 & Sand $(\%)$ & 62 & Sandy Clay Loam \\
\hline & & Dust (\%) & 8 & (Texture Clay) \\
\hline & & Clay( $(\%)$ & 30 & \\
\hline Che & ical Prope & & & \\
\hline No. & Station & Parameter & value & PPT (1983) \\
\hline 1. & Controls & C-Organik (\%) & 3,18 & high \\
\hline & 1 & & 2,08 & medium \\
\hline & 2 & & 2,31 & medium \\
\hline & 3 & & 2,52 & medium \\
\hline 2. & Controls & KTK (me/100g) & 23,18 & medium \\
\hline & 1 & & 17,20 & medium \\
\hline & 2 & & 17,31 & medium \\
\hline & 3 & & 18,11 & medium \\
\hline 3. & Controls & $\mathrm{pH}$ lapangan & 6,12 & somewhat Sour \\
\hline & 1 & & 5,90 & somewhat Sour \\
\hline & 2 & & 5,75 & somewhat Sour \\
\hline & 3 & & 5,20 & sour \\
\hline 4. & Controls & $\mathrm{pH} \mathrm{H} \mathrm{H}_{2} \mathrm{O}$ & 5,90 & somewhat Sour \\
\hline & 1 & & 5,72 & somewhat Sour \\
\hline & 2 & & 5,66 & somewhat Sour \\
\hline & 3 & & 4,90 & sour \\
\hline 5. & Controls & $\mathrm{pH} \mathrm{KCl}$ & 5,10 & somewhat Sour \\
\hline & 1 & & 4,15 & somewhat Sour \\
\hline & 2 & & 4,18 & somewhat Sour \\
\hline & 3 & & 4,00 & somewhat Sour \\
\hline
\end{tabular}

Source: Primary data output (2013) is processed in Chemical Laboratory, Department of Soil Science, Faculty of Agriculture, Brawijaya University.

Waste produced by washing process is fine sand and sludge containing total mercury compound. This mercury enters into soil by seeping through or overflowing during rainy season. Soil biota such as earthworm living in the sites has ability to bind and to accumulate heavy metal in the cells. It is proved by the existence of total mercury concentrations as 
presented in Table 2 .

Table 2. Mercury concentration in soil and earthworm Lumbricus terrestris

\begin{tabular}{|c|c|c|c|c|c|}
\hline No & Object & Station & $\begin{array}{l}\text { Average } \\
\text { The total } \\
\text { content of } \mathrm{Hg} \\
\text { (ppb) }\end{array}$ & Stdev & Threshold level \\
\hline \multirow[t]{4}{*}{1.} & Land & Controls & 0,65 & 0,07 & $0,07-0,3(\mathrm{mg} / \mathrm{Kg})$ \\
\hline & & Station 1 & 6,5 & 2,12 & (Pirrone et al., 2001) \\
\hline & & Station 2 & 5,5 & 2,121 & \\
\hline & & Station 3 & 4 & 1,414 & \\
\hline \multirow[t]{4}{*}{2.} & Worms & Controls & 0,015 & 0,01 & \\
\hline & & Station 1 & 180 & 28,28 & \\
\hline & & Station 2 & 170 & 56,57 & \\
\hline & & Station 3 & 265 & 77,78 & \\
\hline
\end{tabular}

Source: Primary data output (2013) is processed in Chemical Laboratory, Department of Soil Science, Faculty of Agriculture, Brawijaya University.

Discovered earthworm in the three research sites contain total mercury compound. Total mercury concentrations in earthworm is higher than total mercury concentrations in soil. However, high mercury concentrations in the earthworm does not cause mass mortality of Lumbricus terrestris. Mortality is avoidable since earthworm has cellular mechanism to face mercury contamination in the soil.

To encounter cell damage coming about cell walls of Lumbricus terrestris, the organism has cellular mechanism to minimize the damage by processing HSP70 protein expression. It is seen in immunohistochemistry test result of HSP70 to the cell walls of Lumbricus terrestris as presented in Figure 1. 


\section{MInstitute Macrothink $_{\text {Int }}$}
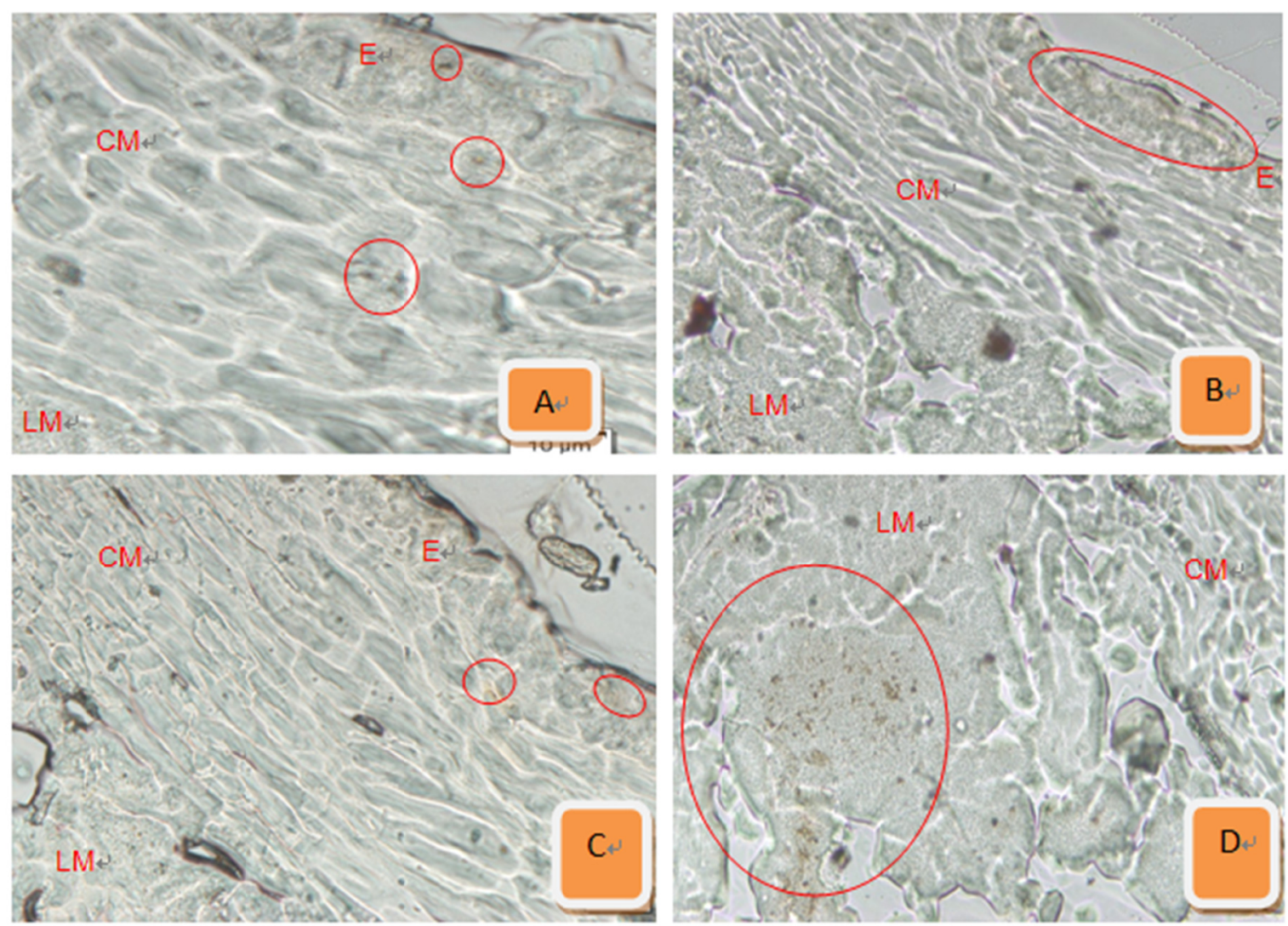

Figure 1 Expression of HSP70 in tissues of the body wall of the earthworm (Lumbricus terrestris) with immunohistochemical test using LSAB + kit, HRP system-HSP70 (3A3): sc-32239 Santa Cruz Biotechnology, Inc. HSP70 expression is marked with a dot-dot colored brown. HSP70 expression in earthworm (Lumbricus terrestris) 400× magnification control (control soil Banjarbaru) is found in the circular muscle (CM). In earthworms in Station 1 Murung Villages Moody HSP70 expressed in the epidermis (E) magnification. Earthworms in the station 2 Pumpung Village 2 HSP70 expressed in the epidermis (E) and circular muscle (CM) and HSP70 expression in earthworms at station 3 ex Used PT. Cempaka Galuh clearly visible and the number of the section there is a lot of longitudinal muscle (LM). For stations 1 , 2 and 3 using $100 \times$ magnification.

\section{Discussion}

Traditional gold mining sites are around Sungai Tiung Sub-district, i.e. Pumpung village and Murung villlage and Palam Sub-district, i.e. Palam village (ex. diamond mining of PT. Galuh Cempaka). Types of soil in the three research sites are yellow red podsolic soil. This type belongs to ordo ultisols. Most types of soil in South Kalimantan is dominated by yellow red podsolic soil (Central Statistics Body of South Kalimantan Province, 1993). Yellow red podsolic soil has poor physical and chemical properties. This type of soil is poor nutrients, high acidity and low cation exchange capacity (Kamprat, 1972; Setijono, 1982 in Syekfani et al., 1997). 
Control parameters for process of absorption and heavy metal distribution in the soil is affected by types of soil, special properties of heavy metal, concentration of heavy metal in the soil, soil $\mathrm{pH}$, contact time, and content of ground water (Heiki, 2004). Reactivity of heavy metal is determined by number of outer electron, high boiling point, and low freezing point. The number of outer electron of an element is odd and small in value and it has high reactivity (Pagenkopf, 1978; Heiki, 2004; Fardiaz, 2005). Mercury has toxicity and the highest reactivity compared to other elements since $\mathrm{Hg}$ has number of outer electron of +1 and +2 (Pagenkopf, 1978; Darmono, 1995).

At the three research sites, soil texture is sandy clay loam at sandy percentage above $40 \%$. Where sandy percentage is $>40 \%$, it usually has some properties such as poor holding capacity, water proof and it tends to hamper water infiltration (Mirdar, 2003). Thus, condition of ex. strip-mine soil in rainy season will be always inundated and eroded easily. Rainfall in Cempaka District is relative high where the soil is regularly wet that the condition fit for life of Lumbricus terrestris. Soil texture of sandy clay loam at the research site may alleviate concentration of mercury in soil, then observed concentration of total mercury is low. Colloidal clay can absorb and bind mercury cation in the soil (Ariyanto, 2001).

Concentration of total mercury in soil at the three research sites is very low around 4-6.5 ppb; it is far below threshold of total mercury concentration which is allowed in soil. Amount of allowed mercury in calcareous soil is $17 \mathrm{mg} / \mathrm{kg}$, acid soil is $6 \mathrm{mg} / \mathrm{kg}$, while critical threshold limit value is 0.5 ppm (Wang et al., 1982 in Rodriguez et al., 2010).

Content of C-organic in soil at the three research sites ranges $2-2.5 \%$. This percentage indicates medium level (Soil Research Center, 1983). The height of C-organic content in the soil affects the amount of total mercury concentration in soil (Alloway and Ayres, 1997). Mercury has strong affinity property to organic matter to form complex compound (Ravichandran, 2004). Accordingly, presence of soil organic matter at medium level can deactivate distribution of toxic mercury ions toward environment and soil biota (Alloway \& Ayres, 1997; Ariyanto, 2001; Ravichandran, 2004).

Increasing organic matter content will be tailed by Cation Exchange Capacity (CEC). Values of CEC at the three research sites are rated medium (Soil Research Center, 1983) that ranging 17.20-18.11 (me/100g) where the highest CEC is found in station 3 (ex. PT. Galuh Cempaka. In the control area, value of CEC reaches the highest compared to the three contaminated sites; it is 23.18 (me/100g). CEC value in three locations at Cempaka District indicates ordo ultisols properties. However, CEC value in these locations is higher than value of CEC in ultisol soil in Kulawi District, Central Sulawesi that reaches 8.55 (me/100g) (Cyio, 2008).

$\mathrm{pH}$ value also affects mercury mobility in soil. Low $\mathrm{pH}$ value can make mercury concentration in the soil high, as well higher mercury toxicity (Ariyanto, 2001; Mirdar, 2003). $\mathrm{pH}$ value in station 4, ex. PT. Galuh Cempaka, is medium that reaches 4.90. In an anaerobic environment with low $\mathrm{pH}$ value, complexes compound of mercury will be unraveled, and it forms toxic ion, i.e. methyl mercury. When soil has other molecules like $\mathrm{Cu}$ and $\mathrm{Zn}$, cation $\mathrm{Hg}$ will be apart from absorption of soil. Such environment can endanger survival rate of Lumbricus terrestris (Jing et al., 2007; Zhang et al., 2009).

In station 1 at Murung village, organic matter content is lower than other stations that 
mercury concentration in the soil is higher than other stations, specifically in station 3 (rice-growing areas ex. PT. Galuh Cempaka). However, $\mathrm{pH}$ in station 3 is highly acid than other stations that mercury toxicity herein gives higher effect on soil biota living underground, for some is earthworm. High mercury toxicity in station 3 causes mortality to the earthworm. It is harder to find earthworm in station 3 than other stations. Low soil $\mathrm{pH}$ can decrease ion release in the soil. Organic acid in soil can make internal methylation process in the body of organism easier. $\mathrm{H}^{+}$ion entering into the body of organism cannot damage the cells, but when $\mathrm{H}^{+}$ion exists, it can make other molecules penetrate into the cells from surrounding environment, especially heavy metal ion $(\mathrm{Hg})$. When cells of an organism is broken, $\mathrm{H}^{+}$ion will penetrate into the cells (Pagenkopf, 1972; Hinton \& Marcello, 1999).

Mercury compound will damage tissues of the worm that inhabit the soil since the soil was contaminated by mercury although mercury concentration is low at $4 \pm 1.41 \mathrm{ppb}$. Mercury compound absorbed by the body of organism will be easily oxidized into highly toxic $\mathrm{Hg}^{+}$or $\mathrm{Hg}^{2+}$ ions. The ions will interact with electrons in the body, where there are poly-electron atoms, such as protein or unsaturated fatty acid. The protein will create groups carboxyl and amino. $\mathrm{Hg}^{+}$, then, will bind with group carboxyl. Besides, $\mathrm{Hg}^{+}$can oxidate unsaturated fatty acid since the $\mathrm{Hg}^{+}$is a strong oxidizer. Mercury, in form of ion, entering into the body of organism triggers formation of free radical chain. In the body of organism, cells can respond and adapt to environmental signal such as the entry of mercury ion. This mercury ion can induct cell damage by increasing ROS, and it also can cause peroxide in the membrane (Suaniti, 2007).

To face cell damage as the consequence of $\mathrm{Hg}$ ion, Lumbricus terrestris takes early protection by processing HSP70 protein expression. This HSP70 protein takes the role to protect the cells, tissues, and whole organ from the worse damage as the impact of environmental stress (Krebs \& Bettencourt, 1999). HSP gene will be active when it receives signal from out of the cell, i.e. a signal when free radical exists. This is an organism defense system because of environmental dissonance. Expression of HSP70 depends on protective function as the result of cell damage and severity of the damage (Sorenson et al., 2003).

Expression of HSP70 in the earthworm is processed in all cell walls in the lengthwise of epidermis, circular muscle and longitudinal muscle. Expression of HSP70 in the cell walls of Lumbricus terrestris in station 3 (rice-growing areas ex. PT. Galuh Cempaka) is found more than living earthworm in the other stations. Expression of HSP70 is indicated by the emergence of brown colored dots spread all over longitudinal muscle as seen in Figure 3 A-D. Earthworm inhabiting environment which was contaminated by heavy metal gets cell damage, while accumulation of heavy metal is found, particularly, in circular muscle and longitudinal muscle (Killic, 2011; Laurenco et al., 2011). This conforms with the findings in this study. It shows a possibility where expression of HSP70 is found in large quantities in longitudinal muscle since $\mathrm{Hg}$ ion accumulates and destructs longitudinal muscle more than other muscle.

\section{Conclusion}

Traditional gold mining activity conducted by people in Cempaka District, Banjarbaru, South Kalimantan can affect negatively organism inhabiting the sites. Concentration of mercury, though, is very low or below threshold of mercury concentration which is allowed in the soil. The most cellular damage is found in longitudinal muscle. As the consequence, most 
expression of HSP70 occurs in this muscle to help curing damaged cell.

\section{Acknowledgements}

Dr. Uun Yanuhar, S. Pi, M. Si and Dr. Rismi Yunita, S. Pi, MS who help us in fundraising and performing immunohistochemistry test in Aquatic Environment and Biotechnology Laboratory, Faculty of Fishery and Marine Science, Brawijaya University. Thanks also go to Dr. Ir. Anik Martina Hariati., M. Sc who gave suggestion for the writing of this article.

\section{References}

Alloway, B. J., \& Ayres, D. C. (1997). Chemical Principles of Environmental Pollution. Blackie Academic \& Professional. London.

Amaral, A., Manu, S., Regina, C., Ionan, M., \& Armindo, R. (2006). Bioavailability and cellular effects of metals on Lumbricus terrestris inhabiting volcanic soils. Environmental Pollution, 142, 103-108. http://dx.doi.org/10.1016/j.envpol.2005.09.011

Ariyanto. Tanpa Tahun. Ikatan Antara Asam Organik Tanah dengan Logam. Jurusan Ilmu Tanah Fakultas Pertanian. Universitas Sebelas Maret Surakarta

Muhammad. B. Cyio. (2008). Efektivitas Bahan Organik Dan Tinggi Genangan Terhadap Perubahan Eh, pH, Dan Status Fe, P, Al Terlarut Pada Tanah Ultisol. J. Agroland, 15(4), 257-263.

Bleeker E. A., \& Jdan Van Gestel C. A. M. (2007). Effects of Spatial and Temporal Variation In Metal Availability On Earthworms In Floodplain Soils of The River Dommel, The Netherlands. Environmental Pollution, $\quad 148, \quad 824-832$. http://dx.doi.org/10.1016/j.envpol.2007.01.034

Feder, M. E., \& Hofmann, G. E. (1999). Heat Shock Proteins, Molecular, Chaperones, and The Stress Response: Evolutionary and Ecological Physiology. Annu. Rev. Physiol., 61, 243-282. http://dx.doi.org/10.1146/annurev.physiol.61.1.243

Heike B. Bradl. (2004). Adsorption of heavy metal ions on soils and soils constituents. Journal of Colloid and Interface Science, 277, 1-18. http://dx.doi.org/10.1016/j.jcis.2004.04.005

Hinton, J., \& Marcello, M. V. (1999). Earthworms As Bioindicators of Mercury Pollution. Geochemistry: Exploration, Environment, Analysis, 2, 269-274. http://dx.doi.org/10.1144/1467-787302-031

Homa J., Olchawa E., Sturzenbaum, S. R., Morgan, A. J., \& Plytycz, B. (2005). Early-Phase Immunodetection of Metallothionein and Heat Shock Proteins In Extruded Earthworm Coelomocytes After Dermal Exposure To Metal Ions. Environmental Pollution, 135, 275-280. http://dx.doi.org/10.1016/j.envpol.2004.10.019

Kamprath, E. J. (1972). Soil Acidity and Liming: In Soils of the Humid Tropics. National Academy of Sciences, Washington DC, pp. 136-149.

Killic, G. A. (2011). Histopathological and biochemical alterations of the earthworm (Lumbricus terrestris) as biomarker of soil pollution along Porsuk River Basin (Turkey). Chemosphere, 83, 1175-1180. http://dx.doi.org/10.1016/j.chemosphere.2010.12.091

Kohler, H. R., Knodler, C., \& Zanger, M. (1999). Divergent Kinetics of HTERRESTRIS70 Induction in Oniscus asellus (Isopoda) in Response to Four Environmentally Relevant 
Organic Chemicals (B[a]P, PCB52, g-HCH, PCP): Suitability and Limits of a Biomarker. Arch. Environ. Contam. Toxicol, 36, 179-185. http://dx.doi.org/10.1007/s002449900458

Krebs, R. A., \&Bettencourt, B. R. (1999). Evolution of Thermotolerance and Variation in The Heat Shock Protein, HSP70. Amer. Zool, 39, 910-919.

Laurenco, J., Ana, S., Fernando, C., Joao, O., Margarida, M., Sonia, M., ... Ruth, P. (2011). Histopathological Changes In The Earthworm Eisenia andrei Associated With The Exposure To Metals And Radionuclides. Chemoterrestrishere, 85, 1630-1634.

Lee K. (1985). Earthworms: Their Ecology and Relationships with Soils and Land Use. (pp. 147-150). Orlando: Academic Press.

Lukkari, T., Taavitsanen, M., Soimasuo, M., Oikari, A., \& Haimi, J. (2004). Biomarker Response of The Earthworm Aporrectodea Tuberculata To Copper And Zinc Exposure: Differences Between Populations With And Without Earlier Metal Exposure. Environmental Pollution, 129, 377-386. http://dx.doi.org/10.1016/j.envpol.2003.12.008

Mirdar, Yosep, Y. P., \& Isrun. (2013). Status Logam Berat Merkuri (Hg) Dalam Tanah Pada Kawasa Pengolahan Tambang Emas Di Kelurahan Poboya, Kota Palu. e-J. Agrotekbis, 1(2), 127-134.

Nadeau, D., Corneau, S., Plante, I., Morrow, G., \& Tanguay, R. M. (2001). Evaluation for HSP70 as Biomarkers of Effect of Pollutants on The Earthworm Lumbricus terrestris. Cell\&Chaperones, 6(2), 153-163.

Pagenkopf, G. K. (1978). Introduction to Natural Water Chemistry. Marcel Dekker, INC. New York and Basel. 271 hal

S. Beltran-Pedreros, Zuanon, J., Leite, R. G., Peleja, J. R. P., Mendonça, A. B., \& Forsberg, B. R. (2011). Mercury bioaccumulation in fish of commercial importance from different trophic categories in an Amazon floodplain lake. Neotropical Ichthyology, 9(4), 901-908. http://dx.doi.org/10.1590/S1679-62252011000400022

Ravichandran, M. (2004). Interactions between mercury and dissolved organic matter a review. Chemosphere, 55, 319-331. http://dx.doi.org/10.1016/j.chemosphere.2003.11.011

Robert, J. (2003). Evolution of Heat Shock Protein and Immunity. Developmental and Comparative Immunology, 27, 449-464. http://dx.doi.org/10.1016/S0145-305X(02)00160-X

Rodriguez, J. A., Nanos, N., Martin, G. C., \& Corbi, J. M. G. (2010). Mercury Soil Pollution on Spanish Islands: Methods to Assess Hg Input. 19th World Congress of Soil Science, Soil Solutions for a Changing World, 1-6 August 2010, Brisbane, Australia.

Suaniti, N. (2007). pengaruh EDTA dalam Penentuan Kandungan Timbal dan Tembaga pada $\begin{array}{lllll}\text { Kerang Hijau } \quad \text { (Mytilus } & \text { Riridis). } & \text { Retrieved }\end{array}$ http://ejournal.unud.ac.id/abstrak/06_suaniti_p(1).pdf

Sorensen, J. G., Kristensen, T. N., \& Loeschcke, V. (2003). The evolutionary and ecological role of heat shock proteins. Ecol. Lett., 6, 1025-1037. http://dx.doi.org/10.1046/j.1461-0248.2003.00528.x

Syekhfani, Sunarto, I., \& Retno, S. (1997). Reklamasi Lahan Unit Pemukiman Transmigrasi (UPT) Cempaka. Seminar sehari penanganan UPT Potensial Bermasalah di Cempaka, Banjarbaru, Kalsel, 3 April 1997, di Banjarmasin. 


\section{Macrothink}

Veiga, M. M., Hinton, J., \& Lily, C. (1999). Mercury in the Amazon: A Comprehensive Review with Special Emphasis on Bioaccumulation and Bioindicators. Proc. NIMD (National Institute for Minamata Disease) Forum'99. pp. 19-39. Oct. 12-13, 1999, Minamata, Japan.

Zhang, Z. S., Zheng, D. M., Wang, Q. C., \& Guo, X. L. (2009). Bioaccumulation of Total and Methyl Mercury in Three Earthworm Species (Drawida terrestris., Allolobophora terrestris., and Limnodrilus terrestris.). Bull Enviroron Contam Toxicol, 83, 937-942. http://dx.doi.org/10.1007/s00128-009-9872-8

\section{Copyright Disclaimer}

Copyright reserved by the author(s).

This article is an open-access article distributed under the terms and conditions of the Creative Commons Attribution license (http://creativecommons.org/licenses/by/3.0/). 